\title{
CHIFFON CARROT CAKE: INOVASI CAKE DENGAN FORTIFIKASI BETAKAROTEN DARI WORTEL DAN PREFERENSI KONSUMEN
}

\author{
Alifya Azhar', Yulia Rahmawati', Ai Mahmudatussa'adah ${ }^{1}$ \\ Program Studi Pendidikan Tata Boga, Departemen Pendidikan Kesejahteraan \\ Keluarga, Fakultas Teknologi dan Kejuruan, Universitas Pendidikan Indonesia
}

\section{alifya.azhar@gmail.com}

\begin{abstract}
Abstrak: Carrot cake merupakan cake dengan tambahan parutan wortel segar didalam adonan. Carrot cake adalah cake klasik yang telah dibuat sejak tahun 1982 dengan karakteristik cake padat, dan memiliki remahan cake yang kasar. Wortel mengandung salah satu pro vitamin A yaitu betakaroten. Betakaroten memiliki banyak manfaat diantaranya mencegah kanker, penyakit kardiovaskuler, peningkat imun tubuh, mencegah katarak, dan age related macular degeneration (AMD) kelainan serius pada retina yang dapat menyebabkan kebutaan. Karakteristik carrot cake klasik justru bertolak belakang dengan masyarakat Indonesia yang cenderung menyukai cake dengan tekstur lembut dan ringan. Sehingga pada penelitian ini peneliti akan membuat inovasi produk carrot cake dengan metode pembuatan cake jenis chiffon cake dengan penambahan wortel bukan berupa parutan tetapi dalam bentuk puree yang selanjutnya akan diberi nama chiffon carrot cake. Hasil penelitian yang dilakukan menyatakan sampel chiffon carrot cake dengan penambahan puree wortel sebanyak $90 \%$ adalah yang paling disukai oleh panelis terlatih. Pengujian daya terima chiffon carrot cake dilakukan kepada 30 panelis tidak terlatih dengan karakteristik penampakan, aroma, rasa, tekstur, dan kesan keseluruhan. Skor uji hedonik dari segi penampakan adalah 87,3\% atau termasuk pada kriteria sangat suka, skor karakteristik aroma adalah 80,7\% atau suka, skor karakteristik rasa 92,7\% atau sangat suka, skor karakteristik tekstur adalah 92,7\% atau sangat suka, skor karakteristik adalah $87,3 \%$ atau sangat suka. Kandungan betakaroten dalam chiffon carrot cake adalah $18,94 \mathrm{mg} / \mathrm{Kg}$..
\end{abstract}

Kata kunci : chiffon carrot cake, betakaroten, preferensi konsumen

\section{PENDAHULUAN}

Industri bakery di Indonesia terus berkembang pesat. Melihat pesatnya perkembangan bakery di Indonesia, perlu dilakukan inovasi poduk bakery yang inovatif salah satunya adalah inovasi produk cake.

Cake merupakan penganan yang tinggi lemak, tinggi gula, minim akan serat dan zat-zat antioksidan. Cake banyak disukai dan dikonsumsi oleh masyarakat. Konsumsi masyarakat terhadap cake meningkat setiap tahunnya. Menurut statistik konsumsi pangan 2015, rata-rata konsumsi makanan dan minuman per kapita dari 2011 hingga 2015. Konsumsi kue mengalami pertumbuhan rata-rata
17,78\% (Setjen Kementan RI, 2015, hlm. 105).

Kandungan zat-zat antioksidan dapat ditambahkan pada cake, salah satunya dengan cara menambahkan bahan lain seperti sayur dan buah yang mengandung banyak zat antioksidan. Salah satu jenis sayuran yang berpotensi untuk ditambahkan pada cake adalah wortel. Wortel (Daucus carota L.) adalah sayuran umbi yang biasanya berwarna oranye, ungu, merah, putih atau kuning dengan tekstur renyah dalam keadaan segar. Wortel kaya akan $\beta$-karoten dan vitamin seperti tiamin, riboflavin, vitamin dan mineral yang kompleks. Penelitian menunjukkan bahwa serat 
pada wortel dan jeruk memiliki kapasitas menahan air yang tinggi (Sharoba, dkk. 2013, hlm. 441). Kapasitas menahan air yang tinggi membuktikan bahwa wortel dan jeruk baik untuk ditambahkan ke dalam produk makanan termasuk kue.

Wortel merupakan salah satu sayuran yang melimpah dan tumbuh baik di wilayah Indonesia. Berdasarkan hasil survey luas panen, produksi dan produktivitas wortel tahun 2013, luas areal panen wortel di Indonesia adalah $32.070 \mathrm{Ha}$ yang tersebar kedalam 22 provinsi. Sedangkan produksi wortel di Indonesia mencapai 512.122 ton. Jawa Barat merupakan provinsi penghasil wortel terbesar kedua setelah Jawa Tengah dengan total produksi wortel mencapai 125.044 ton (Bahar, 2013, hlm. 67).

Wortel adalah sayuran yang memiliki banyak manfaat bagi kesehatan manusia. Kandungan nutrisi per 100 gram wortel segar adalah 42 kkal energi; 9,3 gram karbohidrat; 1,2 gram protein; 0,3 gram lemak; Kalsium $39 \mathrm{mg}$; Fosfor $37 \mathrm{mg}$; 2,8 gram serat; 0,06 $\mathrm{mg}$ vitamin $\mathrm{B} 1$; Vitamin C $6 \mathrm{mg}$; Pro vitamin A (beta karoten) 12.000 SI (Daftar Komposisi Bahan Makanan, 1972). Wortel juga kaya akan antioksidan khususnya mengandung $\beta$-karoten sebagai bahan pengawet alami (Bystrická, dkk. 2015, hlm. 304).

Wortel memiliki manfaat bagi kesehatan tubuh diantaranya antikarsinogenik atau zat anti kanker, antioksidan dan alat peningkat imun tubuh, juga mengandung pro vitamin A yang membentuk betakaroten (Tanaka, dkk. 2012, hlm. 12; Fiedor and Burda, 2014, hlm. 1).

Betakaroten merupakan suatu zat alami yang sangat penting dan mempunyai sifat larut dalam lemak atau pelarut organik tetapi tidak larut dalam air yang merupakan suatu kelompok pigmen berwarna orange, merah atau kuning. Senyawa ini ditemukan tersebar luas dalam tanaman dan buah-buahan dan tidak diproduksi oleh tubuh manusia (Madhavi, dkk. 1995, hlm. 74).

Carrot cake merupakan cake dengan bahan tambahan berupa wortel yang dicampurkan ke dalam adonan. Carrot cake merupakan hidangan klasik. Carrot cake memiliki tekstur agak padat dan memiliki remah yang kasar karena mengandung parutan wortel.

Hal ini justru bertentangan dengan masyarakat Indonesia yang memiliki kecenderungan menyukai cake yang lembut, ringan, mempunyai rasa yang enak dan warna yang cantik. Masyarakat mulai meningkat kesadarannya akan makanan yang lebih sehat dan bergizi. Sehingga pada penelitian ini peneliti akan membuat pengembangan produk carrot cake dengan metode pembuatan cake jenis chiffon cake dengan penambahan wortel bukan berupa parutan tetapi dalam bentuk puree yang selanjutnya akan diberi nama chiffon carrot cake.

\section{METODE}

Metode penelitian yang digunakan penulis dalam penelitian ini adalah eksperimen. Eksperimen merupakan metode penelitian yang digunakan untuk mencari pengaruh perlakuan tertentu terhadap yang lain dalam kondisi yang terkendalikan (Sugiyono, 2006, hlm. 80). Penelitian ini merupakan penelitian eksperimental murni dengan Rancangan Acak Lengkap (RAL) untuk pengembangan formula cake 
dan untuk mengetahui daya terima produk.

Adapun jumlah komposisi bahan cake yang digunakan pada setiap formulasi penelitian adalah dengan menambahkan puree wortel pada adonan cake dengan 4 jenis perlakuan yang berbeda-beda antara lain F0 (Cake tanpa penambahan puree wortel) F1(penambahan puree wortel $50 \%$ dari total cairan), F2 (penambahan puree wortel $70 \%$ dari total cairan), F3(penambahan puree wortel $90 \%$ dari total cairan).

Pengumpulan data melalui angket atau kuesioner uji hedonik (kesukaan). Uji ini terdiri dari daya terima 5 skala likert, skor $1=$ sangat tidak suka, $2=$ tidak suka, $3=$ netral, 4 = suka, $5=$ sangat suka. Sampel cake dinilai oleh panelis terlatih yaitu mahasiswa Program Studi Pendidikan Tata Boga yang lolos seleksi dan wawancara untuk menjadi panelis terlatih sebanyak 15 orang dan panelis tidak terlatih pada uji daya terima yaitu panelis terlatih sebanyak 30 orang. Setelah dilakukan uji daya terima, produk akan diuji di laboratorium untuk mengetahui berapa kandungan betakaroten yang terdapat pada carrot cake dengan metode HPLC (High Performance Liquid Chromatography) di Laboratorium Saraswanti Bogor.

\section{HASIL DAN PEMBAHASAN}

Percobaan pada tahap ini menggunakan metode Rancangan Acak Lengkap (RAL). Adapun jumlah komposisi bahan cake yang digunakan pada setiap formulasi penelitian adalah dengan menambahkan puree wortel pada adonan cake dengan 3 jenis perlakuan yang berbeda-beda antara lain F0 (Cake tanpa penambahan puree wortel), F1 (penambahan puree wortel $50 \%$ dari total cairan), F2 (penambahan puree wortel $70 \%$ dari total cairan), F3 (penambahan puree wortel $90 \%$ dari total cairan). Hasil formula terbaik yang disukai panelis terlatih selanjutnya akan diuji daya terima oleh panelis tidak terlatih dan diuji kandungan betakaroten di laboratorium Saraswanti Bogor.

Pada penelitian ini wortel yang akan ditambahkan kedalam cake diolah menjadi puree. Puree merupakan produk olahan dari penghancuran makanan. Pengolahan puree wortel dapat mempertahankan warna karena telah melalui proses blanching dan penghancuran. Langkah awal dalam pembuatan puree wortel adalah pencucian wortel, pengupasan wortel, pemotongan wortel, dan proses blanching atau proses merebus cepat. Proses blanching dilakukan selama 2-5 menit dalam air mendidih, proses ini dilakukan untuk mempertahankan nutrisi dan warna pada wortel. Tahap kedua adalah proses penghancuran wortel menjadi puree wortel menggunakan blender.

Penambahan puree wortel ke dalam carrot cake untuk mencari produk yang berkualitas diperlukan beberapa perlakuan yang berbeda. Adapun persentase penambahan puree wortel dalam penelitian ini dapat diamati pada tabel 1 .

Tabel 1. Jenis dan Ukuran Bahan dalam Pembuatan chiffon carrot cake

\begin{tabular}{lcccc}
\multicolumn{5}{c}{ cake } \\
\hline \multirow{2}{*}{ Bahan } & \multicolumn{4}{c}{ Persentase penambahan puree } \\
& $0 \%$ & $50 \%$ & $70 \%$ & $90 \%$ \\
\cline { 2 - 5 } & $0 \mathrm{~g}$ & $60 \mathrm{~g}$ & $84 \mathrm{~g}$ & $108 \mathrm{~g}$ \\
\hline Puree wortel & $120 \mathrm{~g}$ & $60 \mathrm{~g}$ & $36 \mathrm{~g}$ & $12 \mathrm{~g}$ \\
\hline Susu cair & $5 \mathrm{btr}$ & $5 \mathrm{btr}$ & $5 \mathrm{btr}$ & $5 \mathrm{btr}$ \\
\hline Kuning telur & $1 \mathrm{btr}$ & $1 \mathrm{btr}$ & $1 \mathrm{btr}$ & $1 \mathrm{btr}$ \\
\hline Telur utuh & & & & \\
\hline
\end{tabular}




\begin{tabular}{lcccc}
\hline $\begin{array}{l}\text { Minyak } \\
\text { sayur }\end{array}$ & $50 \mathrm{~g}$ & $50 \mathrm{~g}$ & $50 \mathrm{~g}$ & $50 \mathrm{~g}$ \\
\hline $\begin{array}{l}\text { Tepung } \\
\text { terigu }\end{array}$ & $95 \mathrm{~g}$ & $95 \mathrm{~g}$ & $95 \mathrm{~g}$ & $95 \mathrm{~g}$ \\
\hline $\begin{array}{l}\text { Kayumanis } \\
\text { bubuk }\end{array}$ & $3 \mathrm{~g}$ & $3 \mathrm{~g}$ & $3 \mathrm{~g}$ & $3 \mathrm{~g}$ \\
\hline Putih telur & $5 \mathrm{btr}$ & $5 \mathrm{btr}$ & $5 \mathrm{btr}$ & $5 \mathrm{btr}$ \\
\hline Gula & $90 \mathrm{~g}$ & $90 \mathrm{~g}$ & $90 \mathrm{~g}$ & $90 \mathrm{~g}$ \\
\hline Garam & $1 \mathrm{~g}$ & $1 \mathrm{~g}$ & $1 \mathrm{~g}$ & $1 \mathrm{~g}$ \\
\hline $\begin{array}{l}\text { Air jeruk } \\
\text { lemon }\end{array}$ & $5 \mathrm{~g}$ & $5 \mathrm{~g}$ & $5 \mathrm{~g}$ & $5 \mathrm{~g}$ \\
\hline
\end{tabular}

Setelah dilakukan uji coba pembuatan sampel kemudian uji ranking hedonik untuk mengetahui dan mengukur tingkat kesukaan terhadap produk chiffon carrot cake secara keseluruhan dari keempat sampel tersebut. Sampel yang paling disukai atau yang paling banyak berada di peringkat satu akan digunakan untuk uji hedonik kepada panelis tidak terlatih. Pengolahan data uji ranking hedonik menghasilkan nilai kesukaan terhadap chiffon carrot cake yang disajikan pada gambar 1 .

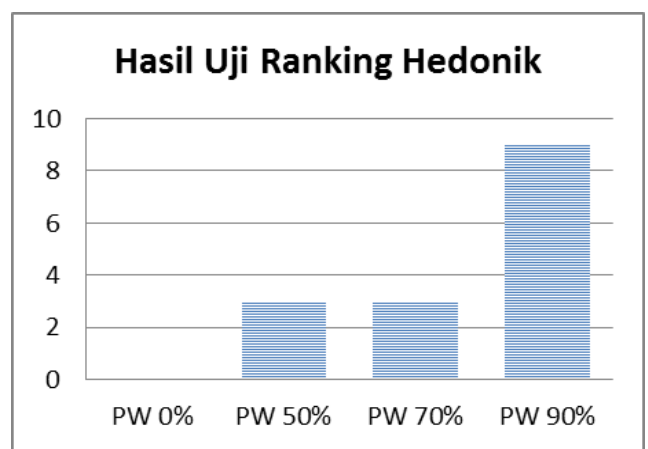

Gambar 1. Hasil Uji Ranking Hedonik Chiffon Carrot Cake

Pada gambar 4.7. dapat diketahui bahwa dari 15 panelis tidak ada yang memilih cake tanpa penambahan puree wortel (PW 0\%), 3 dari 15 orang panelis memilih sampel cake dengan penambahan puree wortel sebanyak 50\% (PW 50\%), 3 dari 15 orang panelis memilih sampel cake dengan penambahan puree wortel sebanyak 70\% (PW 70\%), sebanyak 9 dari 15 panelis memilihi chiffon carrot cake penambahan puree wortel $90 \%$ (PW 90\%), oleh karena itu sampel dengan penambahan puree wortel $90 \%$ memiliki tingkat kesukaan paling tinggi dibandingkan dengan sampel chiffon carrot cake yang lain dan akan digunakan sebagai formula acuan pada uji hedonik oleh panelis tidak terlatih.

Uji hedonik dilakukan dengan cara membagikan sampel chiffon carrot cake terbaik yaitu dengan penambahan puree wortel $90 \%$ kepada 30 orang panelis tidak terlatih, panelis menyatakan tingkat kesukaannya berdasarkan 5 kriteria yaitu penampakan, aroma, rasa, tekstur dan kesan keseluruhan. Hasil uji hedonik produk chiffon carrot cake adalah sebagai berikut:

\section{A. Penampakan}

Penampakan merupakan karakteristik pertama yang dapat dinilai secara langsung oleh konsumen. Penilaian penampakan ini bertujuan untuk mengetahui penerimaan panelis berdasarkan penampakan permukaan dan warna dari chiffon carrot cake. Hasil uji hedonik terhadap penampakan chiffon carrot cake dapat diamati pada gambar 2.

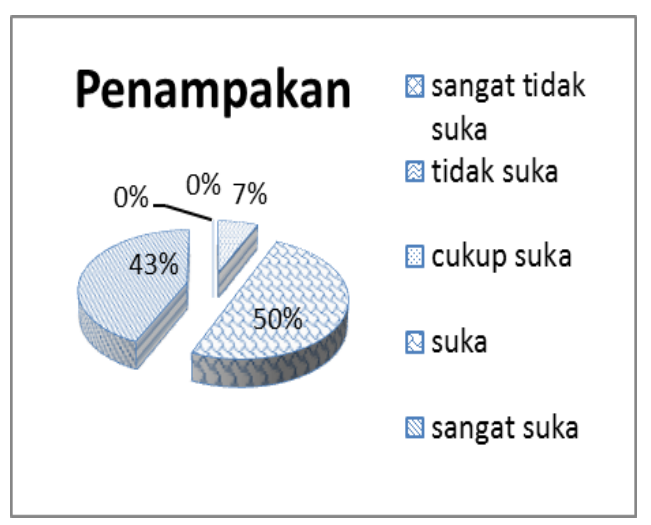

Gambar 2. Chart hasil uji hedonik penampakan produk chiffon carrot cake 
Berdasarkan pengolahan data hasil uji hedonik produk carrot chiffon carrot cake, ditinjau dari kategori penampakan sebanyak $7 \%$ menyatakan cukup suka pada produk chiffon carrot cake, $50 \%$ panelis menyatakan suka pada produk chiffon carrot cake, dan $43 \%$ panelis menyatakan sangat suka terhadap produk chiffon carrot cake. Persentase panelis yang menyatakan tidak suka terhadap produk adalah $0 \%$ dan panelis yang menyatakan sangat tidak suka terhadap produk chiffon carrot cake adalah 0\%. Dapat disimpulkan bahwa tingkat kesukaan produk chiffon carrot cake dari segi penampakan, panelis menyatakan suka dan produk diterima secara positif oleh konsumen.

\section{B. Aroma}

Aroma merupakan salah satu parameter yang menentukan mutu suatu produk olahan. Aroma atau bau makanan dapat menentukan kelezatan suatu produk. Hasil uji hedonik terhadap aroma chiffon carrot cake dapat diamati pada gambar 3 .

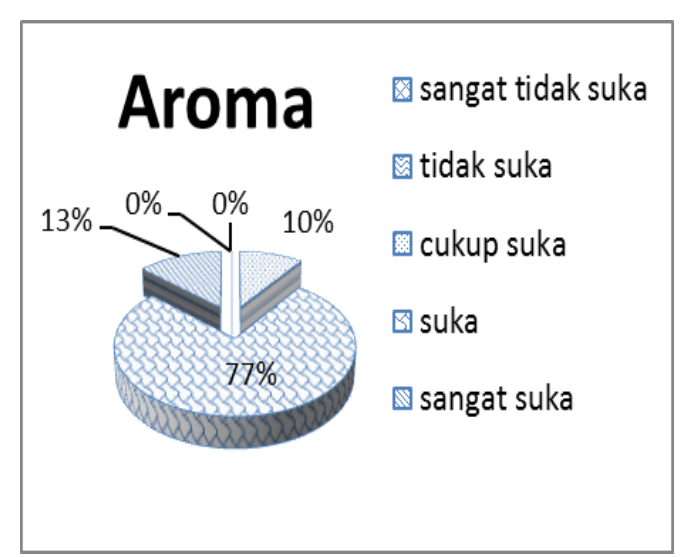

Gambar 3. Chart hasil uji hedonik aroma produk chiffon carrot cake

Berdasarkan pengolahan data hasil uji hedonik produk carrot chiffon carrot cake, ditinjau dari kategori aroma sebanyak $10 \%$ menyatakan cukup suka pada aroma produk chiffon carrot cake, $77 \%$ panelis menyatakan suka pada aroma produk chiffon carrot cake, dan $13 \%$ panelis menyatakan sangat suka terhadap aroma produk chiffon carrot cake. Persentase panelis yang menyatakan tidak suka terhadap aroma produk adalah 0\% dan panelis yang menyatakan sangat tidak suka terhadap aroma produk chiffon carrot cake adalah 0\%. Dapat disimpulkan bahwa tingkat kesukaan produk chiffon carrot cake dari segi aroma, panelis menyatakan suka dan produk diterima secara positif oleh konsumen.

C. Rasa

Rasa merupakan parameter penting untuk menentukan diterima atau tidaknya suatu produk, setinggi apapun kandungan gizinya apabila rasanya tidak disukai makan produk tersebut akan ditolak oleh panelis. Hasil uji hedonik terhadap aroma chiffon carrot cake dapat diamati pada gambar 4.

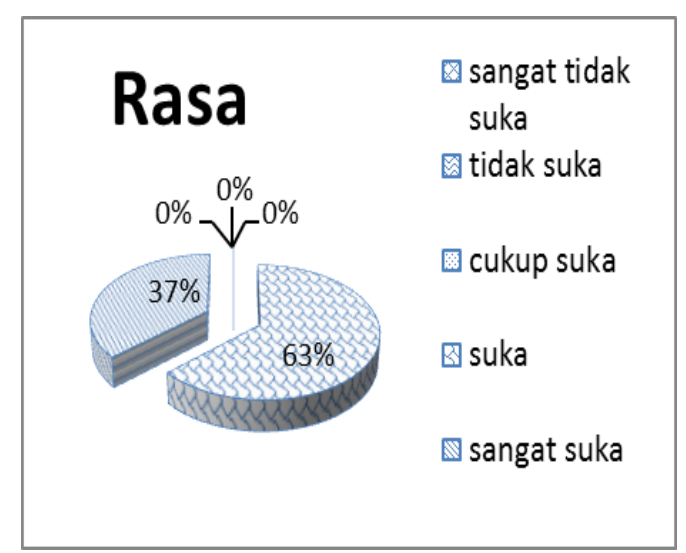

Gambar 4. Chart hasil uji hedonik rasa produk chiffon carrot cake

Berdasarkan pengolahan data hasil uji hedonik produk carrot chiffon carrot cake, ditinjau dari kategori rasa sebanyak $63 \%$ panelis menyatakan suka pada rasa produk chiffon carrot 
cake, dan $37 \%$ panelis menyatakan sangat suka terhadap rasa produk chiffon carrot cake. Persentase panelis yang menyatakan cukup suka adalah $0 \%$, tidak suka terhadap rasa produk adalah $0 \%$ dan panelis yang menyatakan sangat tidak suka terhadap rasa produk chiffon carrot cake adalah 0\%. Dapat disimpulkan bahwa tingkat kesukaan produk chiffon carrot cake dari segi rasa, panelis menyatakan suka dan produk diterima secara positif oleh konsumen.

\section{Tekstur}

Tekstur merupakan salah satu faktor yang menentukan penerimaan suatu produk, penilaian tekstur bertujuan untuk mengetahui penerimaan panelis terhadap tingkat kepadatan cake menggunakan indra peraba. Hasil uji hedonik terhadap aroma chiffon carrot cake dapat diamati pada gambar 5 .

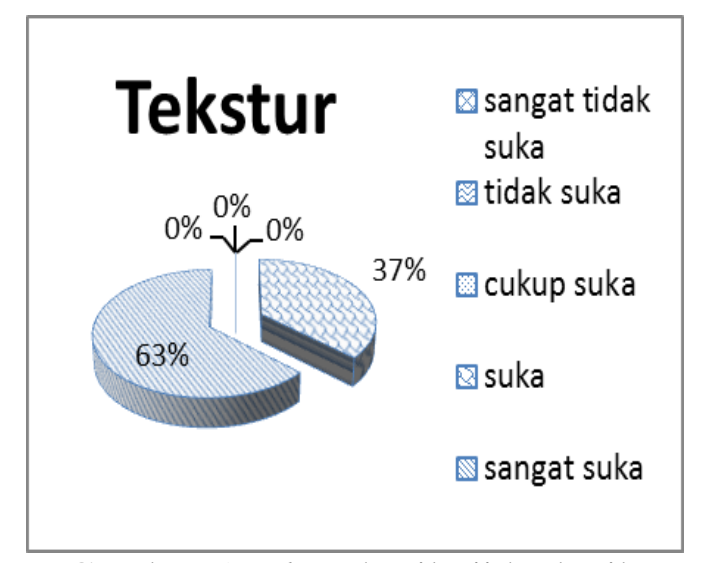

Gambar 5. Chart hasil uji hedonik tekstur produk chiffon carrot cake

Berdasarkan pengolahan data hasil uji hedonik produk carrot chiffon carrot cake, ditinjau dari kategori tekstur sebanyak $63 \%$ panelis menyatakan suka pada tekstur produk chiffon carrot cake, dan $37 \%$ panelis menyatakan sangat suka terhadap tekstur produk chiffon carrot cake.
Persentase panelis yang menyatakan cukup suka adalah $0 \%$, tidak suka terhadap tekstur produk adalah $0 \%$ dan panelis yang menyatakan sangat tidak suka terhadap tekstur produk chiffon carrot cake adalah 0\%. Dapat disimpulkan bahwa tingkat kesukaan produk chiffon carrot cake dari segi tekstur, panelis menyatakan suka dan produk diterima secara positif oleh konsumen.

\section{E. Kesan Keseluruhan}

Kesan keseluruhan adalah tingkat penerimaan panelis secara umum atau keseluruhan setelah mencicipi produk chiffon carrot cake. Hasil uji hedonik terhadap aroma chiffon carrot cake dapat diamati pada gambar 6.

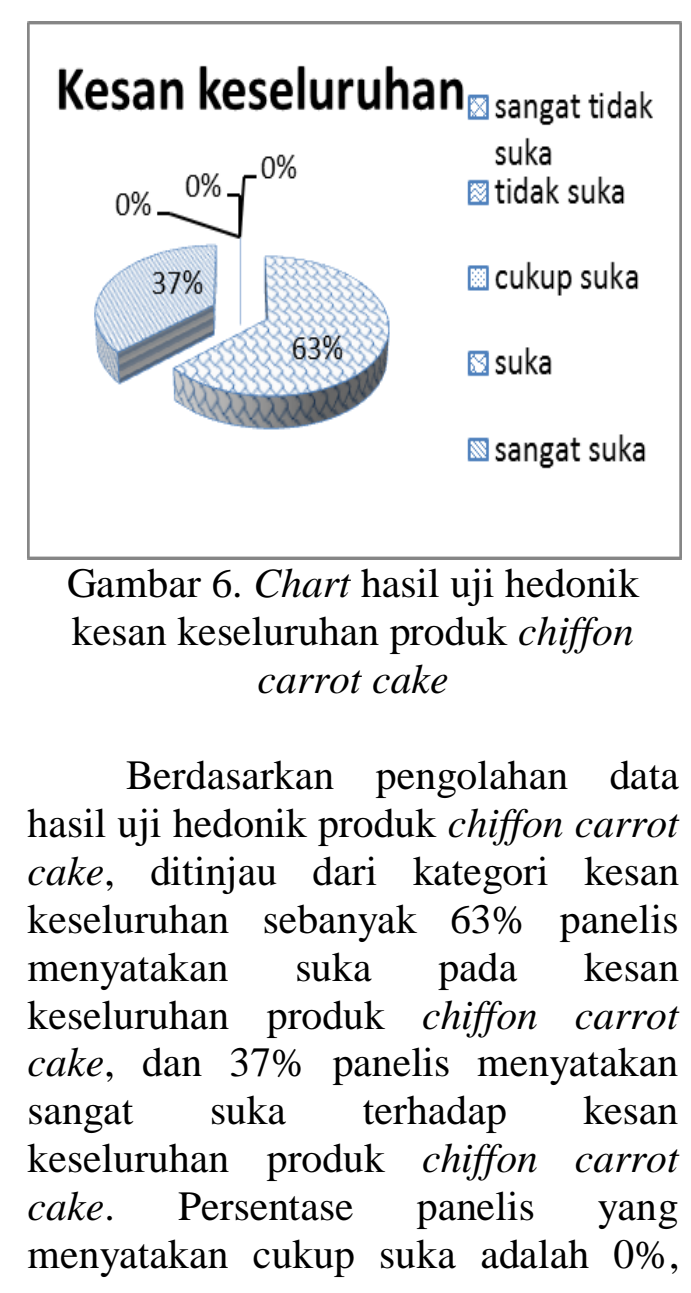


tidak suka terhadap kesan keseluruhan produk adalah $0 \%$ dan panelis yang menyatakan sangat tidak suka terhadap kesan keseluruhan produk chiffon carrot cake adalah 0\%. Dapat disimpulkan bahwa tingkat kesukaan produk chiffon carrot cake dari segi kesan keseluruhan, panelis menyatakan suka dan produk diterima secara positif oleh konsumen.

\section{F. Uji Betakaroten}

Uji betakaroten dilakukan di Laboratorium Saraswanti Bogor dengan metode High Performance Liquid Chromatography (HPLC). Berdasarkan hasi pengujian betakaroten yang terkandung dalam chiffon carrot cake dengan penambahan puree wortel 90 dari total cairan adalah $18,94 \mathrm{mg} / \mathrm{Kg}$ atau dapat dikonversikan menjadi satuan mikrogram $18940 \quad \mu \mathrm{g} / \mathrm{Kg}$. Pada penyajian $100 \mathrm{~g}$ chiffon carrot cake terdapat $1894 \mu \mathrm{g} / 100 \mathrm{~g}$. Kebutuhan vitamin A yang dianjurkan berdasarkan angka kecukupan gizi disetarakan dengan kategori laki-laki dewasa dengan aktivitas ringan adalah $700 \mu \mathrm{g}$ retinol setara dengan $4200 \mu \mathrm{g}$ betakaroten. Mengkonsumsi 1 porsi atau $100 \mathrm{~g}$ chiffon carrot cake dapat memenuhi $45 \%$ dari total kebutuhan betakaroten harian pada tubuh manusia.

\section{KESIMPULAN}

Produk chiffon carrot cake merupakan inovasi produk cake dengan penambahan puree wortel dengan menggunakan formula dasar cake jenis chiffon cake. Chiffon cake dipilih karena teksturnya yang ringan dan memiliki kandungan air yang cukup banyak sehingga cairan yang terkandung didalam adonan dapat disubstitusi dengan puree wortel.
Chiffon carrot cake dibuat untuk menciptakan produk carrot cake yang lebih lembut dan ringan dari carrot cake yang sudah ada dipasaran dengan mengganti metode pembuatan cake dengan tujuan dapat diterima oleh konsumen

Hasil penelitian yang dilakukan menyatakan sampel chiffon carrot cake dengan penambahan puree wortel sebanyak $90 \%$ adalah yang paling disukai oleh panelis terlatih. Pengujian daya terima chiffon carrot cake dilakukan kepada 30 panelis tidak terlatih dengan karakteristik penampakan, aroma, rasa, tekstur, dan kesan keseluruhan. Skor uji hedonik dari segi penampakan adalah $87,3 \%$ atau termasuk pada kriteria sangat suka, skor karakteristik aroma adalah $80,7 \%$ atau suka, skor karakteristik rasa $92,7 \%$ atau sangat suka, skor karakteristik tekstur adalah $92,7 \%$ atau sangat suka, skor karakteristik adalah $87,3 \%$ atau sangat suka. Kandungan betakaroten yang terdapat pada 1 porsi atau 100 gram chiffon carrot cake setelah dilakukan pengujian dengan metode HPLC adalah $1894 \mu \mathrm{g} / \mathrm{Kg}$.

\section{REFERENSI}

Anonim. (1972). Daftar Komposisi Bahan Makanan. Direktorat Jendral Pangan dan Gizi. Departemen Kesehatan RI, Jakarta

Bahar, H. Y. (2013). Statistik Produksi Holtikultura 2013. Jakarta: Direktorat Jenderal Holtikultura, Kementrian Pertanian.

Bystricka, J. dkk. (2015). Carrot (Daucus carota L. ssp. sativus (Hoffm.) Arcang.) as source of antioxidants. Acta agriculturae Slovenica, 105(2), pp.303-311. doi: $\quad$ http://aas.bf.uni- 
lj.si/september2015/13_Bystrick a.pdf.

Fiedor J., Burda K. 2014. Potential

Role of Carotenoids as

Antioxidants in Human Health and Disease. Nutriens, 6:466488, doi: $10.3390 /$ nu6020466

Madhavi, D. L., dkk. (1995). Food Antioxidant, Technological, Toxicological, and Health Perspectives. New york - Bassel - Hongkong: Marcel Dekker, inc.

Sekertariat Jendral Kementrian Pertanian Republik Indonesia. (2015). Statistik Konsumsi Pangan 2015. [Online]. Diakses dari:

$\underline{\text { http://epublikasi.setjen.pertanian }}$
.go.id/epublikasi/StatistikPertani an/2015/

Sharoba, A.M., Farrag, M.A. \& ElSalam, A. (2013). Utilization of some fruits and vegetables waste as a source of dietary fiber and its effect on the cake making and its quality attributes. Journal of Agroalimentary Processes and Technologies, 19(4), pp.429444.

Tanaka T., Shnimizu M., Moriwaki H. (2012).

Cancer

Chemoprevention by

Carotenoids. Molecules, 17: 3202-3242, doi: 10.3390/molecules17033202. 